\title{
Prosthetic Requirement for Laser Crown Lengthening in Chennai Population - A Retrospective Study
}

Research Article

\author{
Godlin Jeneta J1, Rakshagan V²*, Nivedhitha M.S ${ }^{3}$
}

${ }^{1}$ Saveetha Dental College and Hospitals, Saveetha Institute of Medical and Technical Sciences, Saveetha University, Chennai, India.

${ }^{2}$ Senior Lecturer, Department of Prosthodontics, Saveetha Dental College and Hospitals, Saveetha Institute of Medical and Technical Sciences, Saveetha University, Chennai, India.

${ }^{3}$ Professor and Head of Academics, Dept of Conservative Dentistry \& Endodontics, Saveetha Dental College and Hospitals, Saveetha Institute of Medical and Technical Sciences Saveetha University, Chennai 77, India.

\section{Abstract}

Crown lengthening is done to increase exposure of tooth structure by partially removing the supporting periodontal tissues. Lasers in crown lengthening is widely accepted nowadays both by the practitioner and patients due its wide range of advantages. The aim of this study is to evaluate the prosthetic requirement for laser crown lengthening in the Chennai population. This is a retrospective study and the data was obtained from the past case records of patients. The study was done in a university setting. The total sample size of the study was 74 patents who underwent laser crown lengthening in the anteriors and premolars during the period of june 2019 to march 2020 were included in the study. All the necessary information was collected and entered in Microsoft excel spreadsheet and subsequently transferred to SPSS version 23.0 for statistical analysis. Chi square tests were employed to find the association between different variables and $\mathrm{p}<5 \%$ was considered statistically significant. Out of 74 individuals, $46.25 \%$ were males and $55.75 \%$ were females. The mean of the male and female who underwent laser crown lengthening was $29.35 \pm 9.7$ and $33.73 \pm 13$ respectively. $40.54 \%$ had undergone crown lengthening in the upper arch due to endodontic treatment. $25.68 \%$ of males had undergone crown lengthening due to endodontic treatment. $31.08 \%$ of individuals who had undergone crown lengthening due to endodontic treatment were between the age of 31 to 50 years. $29.73 \%$ of the individuals were male below 30 years of age. Statistical significant association was seen between the age and reason for crown lengthening $(p=0.001)$. Within the limits of the study, it was seen the most common reason for laser crown lengthening was endodontic treatment followed by orthodontic treatment and prosthodontic treatment.

Keywords: Endodontic Treatment; Laser Crown Lengthening; Orthodontic Treatment; Prosthodontic Treatment.

\section{Introduction}

Numerous clinical situations are encountered by dentists everyday. Few of them are subgingival caries, fractured teeth. Crown lengthening is done to expose sufficient tooth structure to facilitate proper restoration as well as enhance the aesthetic appearance [1]. Various indications for crown lengthening are subgingival caries exposure, access to subgingival root paerforations, correction of gummy smile, exposure of fractured teeth. Most important factor to be considered during crown lengthening is biological width. It is the amount of soft tissue attached to the tooth above the alveolar crest. Biological width should be at the least $2.04 \mathrm{~mm}$. $0.97 \mathrm{~mm}$ of epithelial attachment and $1.07 \mathrm{~mm}$ of connective tis- sue attachment with $1 \mathrm{~mm}$ of sulcus depth [2].

Based on clinical scenario, procedure is categorised into aesthetic and functional. In some situations crown lengthening is done for both cases. Reasons to do crown lengthening in endodontic or prosthodontic treated patients is that the extension of restorative margin below the biologic width causes gingival inflammation and resorption of crestal alveolar bone [3]. Hence crown lengthening in these patients are done to maintain the health of the periodontium [4]. Aesthetic crown lengthening is done to correct the gingival asymmetry and correction of clinically short crowns which is caused due to altered passive eruption leading to gummy smile [5]. For prosthetic requirements, crown lengthening is done if there is

\section{*Corresponding Author}

Rakshagan V,

Senior Lecturer, Department of Prosthodontics, Saveetha Dental College and Hospitals, Saveetha Institute of Medical and Technical Sciences, Saveetha University, Chennai 77, India. Tel: 9841990565

E-mail: rakshagan.sdc@saveetha.com

Received: October 28, 2019

Accepted: November 24, 2019

Published: November 28, 2019

Citation: Godlin Jeneta J, Rakshagan V, Nivedhitha M.S. Prosthetic Requirement for Laser Crown Lengthening in Chennai Population - A Retrospective Study. Int J Dentistry Oral Sci. 2019;S5:02:001:1-5. doi: http://dx.doi.org/10.19070/2377-8075-SI02-05001

Copyright: Rakshagan $V^{\circ}$ 2019. This is an open-access article distributed under the terms of the Creative Commons Attribution License, which permits unrestricted use, distribution and reproduction in any medium, provided the original author and source are credited. 
insufficient clinical crown, difficult in placement of finish line [6].

Crown lengthening procedures are accompanied by uses of scalpel or laser [7]. Laser is mostly accepted both by the dentist and patients due to its various advantages. The bloodless nature of laser therapy provides good visualisation for clinicians [8]. Compared to scalpel, lasers can easily reshape oral soft tissue [9]. Lasers produce less wound contraction and minimal scarring [10]. The crown lengthening in the aesthetic zone has progressively increased due to the smile enhancement therapy. It is essential for dentists to understand the diagnostic criteria, treatment planning and biological parameters as well as surgical and restorative protocols to enhance predictable outcomes in the aesthetic zone.

Many clinical studies, in vitro and in vivo studies have been done by our team in saveetha dental college in the department of prosthodontics over the past 5 years [11-25]. Now we are focusing on epidemiological studies. Hence the present study was done to evaluate the prosthetic requirement for laser crown lengthening in the Chennai population.

\section{Materials and Methods}

The study was in a University setting. Study includes patients who underwent crown lengthening in the anterior region (aesthetic zone). Sample size is 74 . The study was a retrospective unicentric observational study. Ethical approval from university ethics committee. Data was collected from DIAS where the dental and medical history of the patients were recorded. The data tabulation done in excel sheet and transferred to SPSS for data analysis. Chisquare test was done.

\section{Study design}

This is a retrospective study conducted in a private dental institution. The patient case records were reviewed for the necessary information by a trained examiner. The advantage of conducting the study in an institutional set up provides easy access to patient records. Among patients who have visited the dental clinic of the institution, the case records of 74 patients were reviewed. A wide age range is selected for the study. The institutional ethical committee provided approval for the study (SDC/SIHEC/2020/DIASDATA/0618-0319).

\section{Inclusion criteria}

1. Patients who had undergone laser crown lengthening in anterior and premolar region

2. Patients from $<30$ years to $>51$ years of age

\section{Exclusion criteria}

1. Incomplete patient data

2. Duplicate patient data

3. Laser crown lengthening in molars

\section{Sampling}

A total of 74 case records of patients who underwent laser crown lengthening were reviewed to find out the reason for crown lengthening. Convenient sampling method was used to select the patients for the study. The data obtained from the case records were cross verified with photographs.

\section{Data collection}

All the data after thorough checking for duplicates, incomplete entries and cross verification with photographs were entered in Microsoft excel spread sheet in order to organise the data. The variables obtained from the data included age, gender, arch, and reason for crown lengthening. Here the age, gender are the independent variables and, the reason for crown lengthening is the dependent variable.

\section{Statistics}

The statistical analysis of the obtained data was performed by the SPSS software version 23.0. The data from the excel spreadsheet was transferred to SPSS software for analysis. Chi square tests were employed in order to find the association between different variables. The $\mathrm{p}$ value less than $5 \%$ was considered statistically significant. The final results are presented in the form of graphs for further interpretation and discussion.

\section{Results and Discussion}

Numerous conditions require crown lengthening such as unaesthetic gingival heights, inadequate crown length, subgingival caries, crown fracture [26]. Crown lengthening can be done if the sulcus depth is more than $4 \mathrm{~mm}[27]$.

Total of 74 patients were included in this study. All these patients had undergone laser crown lengthening in the anterior or premolar region due to either endodontic, prosthodontic or orthodontic reason. Out of 74 patients $46.25 \%$ were males and $55.75 \%$ were females. The mean of the males who underwent laser crown lengthening was $29.35 \pm 9.7$ and the mean of females who underwent laser crown lengthening was $33.73 \pm 13$.

The distribution of arch and reason for crown lengthening was studied of which, $40.54 \%$ had undergone crown lengthening in the upper arch due to endodontic treatment, $20.27 \%$ due to orthodontic treatment and $12.16 \%$ due to prosthodontic treatment. $10.81 \%$ had undergone crown lengthening in the lower arch due to endodontic treatment, $6.76 \%$ due to orthodontic treatment and $6.76 \%$ due to prosthodontic treatment. $1.35 \%$ had undergone crown lengthening in both the arch due to orthodontic treatment and $1.35 \%$ due to prosthodontic treatment. There was no statistical significance found between the association of arch and reason for crown lengthening ( $p$ value $=0.487 ; p>0.05$ ). Crown lengthening due to endodontic treatment, prosthodontic treatment and orthodontic treatment was done more in the upper arch (figure 1).

The distribution of gender and reason for crown lengthening was studied of which, $25.68 \%$ of males had undergone crown lengthening due to endodontic treatment, $10.81 \%$ of males due to orthodontic treatment and $9.46 \%$ of males due to prosthodontic treatment. $25.68 \%$ of females had undergone crown lengthening due to endodontic treatment, $17.57 \% \%$ of females due to orthodontic treatment and $10.81 \%$ of females due to prosthodontic treatment. There was no statistical significance found between the association of gender and reason for crown lengthening $(p$ 
value $=0.678 ; \mathrm{p}>0.05)$. Crown lengthening due to endodontic treatment was done more in male and female. Crown lengthening due to prosthetic treatment was done more in males (figure 2).

The distribution of age and reason for crown lengthening was studied of which, $17.57 \%$ of individuals who had undergone crown lengthening due to endodontic treatment were below 30 years, $25.68 \%$ of individuals due to orthodontic treatment and $10.81 \%$ of individuals due to prosthodontic treatment. $31.08 \%$ of individuals who had undergone crown lengthening due to endodontic treatment were between the age of 31 to 50 years, $2.70 \%$ of individuals due to orthodontic treatment and $6.76 \%$ of individuals due to prosthodontic treatment. $2.70 \%$ of individuals who had undergone crown lengthening due to endodontic treatment were above the age group of 51 years, and $2.70 \%$ of individuals due to prosthodontic treatment. There was a statistical significance found between the association of age and reason for crown lengthening ( $\mathrm{p}$ value $=0.001 ; \mathrm{p}<0.05$ ). Crown lengthening due to endodontic treatment was done more between the age group of 31 to 50 . Crown lengthening due to prosthodontic treatment was done more in individuals below 30 years. (figure 3)

The distribution of age and gender of the individuals who undergone crown lengthening was studied of which, $29.73 \%$ of the individuals were male and $24.32 \%$ of the individuals were females below 30 years of age. $16.86 \%$ of the individuals were male and $25.68 \%$ of the individuals were females between 31 to 50 years of age. $1.35 \%$ of the individuals were male and $4.05 \%$ of the individuals were females above 51 years of age. There was no statistical significance found between the association of age and reason for crown lengthening $(\mathrm{p}$ value $=0.216 ; \mathrm{p}>0.05)$. Crown lengthening was done more in males below 30 years. (figure 4 )

This study states that most of the individuals, equally males and

Figure 1. Depicts the association between the arch with the reason for crown lengthening. $X$ axis represents the arch and $\mathrm{Y}$ axis represents the total number of patients. From the present graph it can be inferred that the association between the variables is statistically not significant $(\mathrm{p}$ value $=0.487 ; \mathrm{p}>\mathbf{0 . 0 5}$ ). Crown lengthening due to endodontic treatment was done more in the upper arch.

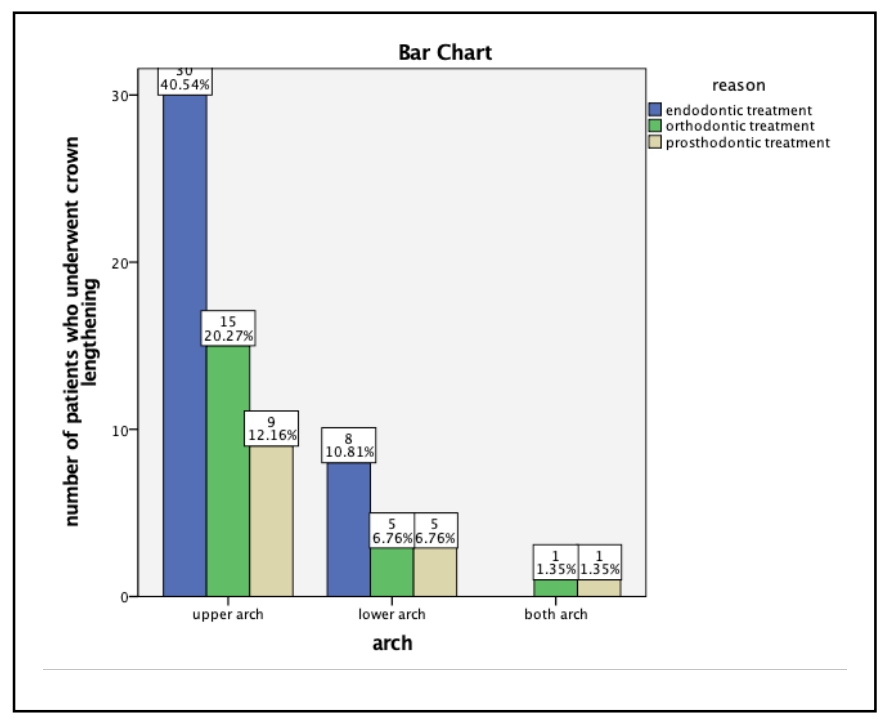

Figure 2. Depicts the association between the gender with the reason for crown lengthening. $\mathrm{X}$ axis represents the gender and $\mathrm{Y}$ axis represents the total number of patients. From the present graph it can be inferred that the association between the variables is statistically not significant ( $p$ value $=0.678 ; p>0.05$ ). Crown lengthening due to endodontic treatment was done more in male and female.

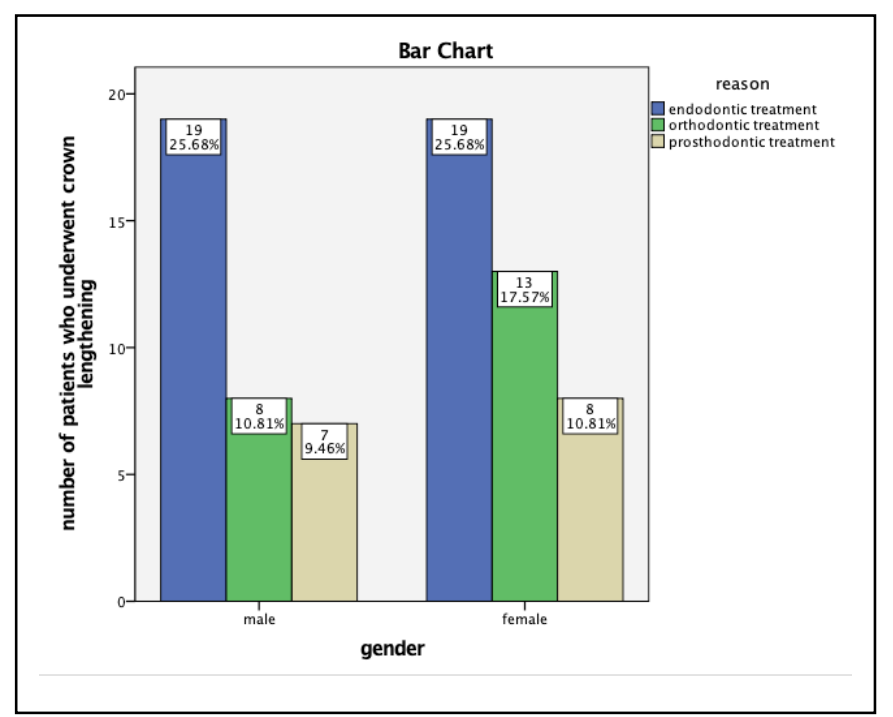


Figure 3. Depicts the association between the age with the reason for crown lengthening. $X$ axis represents the age and $Y$ axis represents the total number of patients. From the present graph it can be inferred that the association between the variables is statistically significant ( $p$ value $=0.001 ; p<0.05$ ). Crown lengthening due to endodontic treatment was done more between the age group of 31 to 50 .

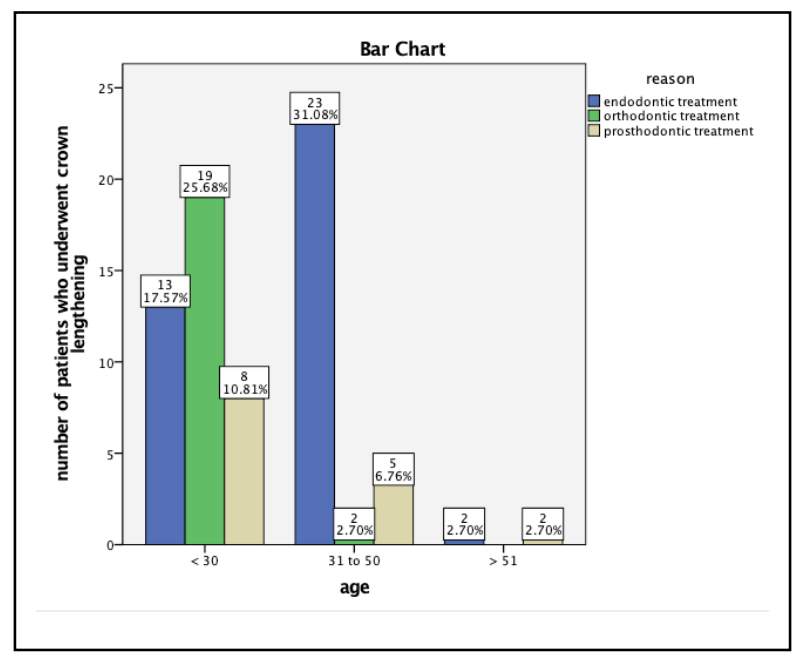

Figure 4. Depicts the association between the gender with the reason for crown lengthening . $\mathrm{X}$ axis represents the age and $\mathrm{Y}$ axis represents the gender. From the present graph it can be inferred that the association between the variables is statistically not significant $(\mathrm{p}$ value $=0.216 ; \mathrm{p}>0.05)$. Crown lengthening was done more in males below 30 years.

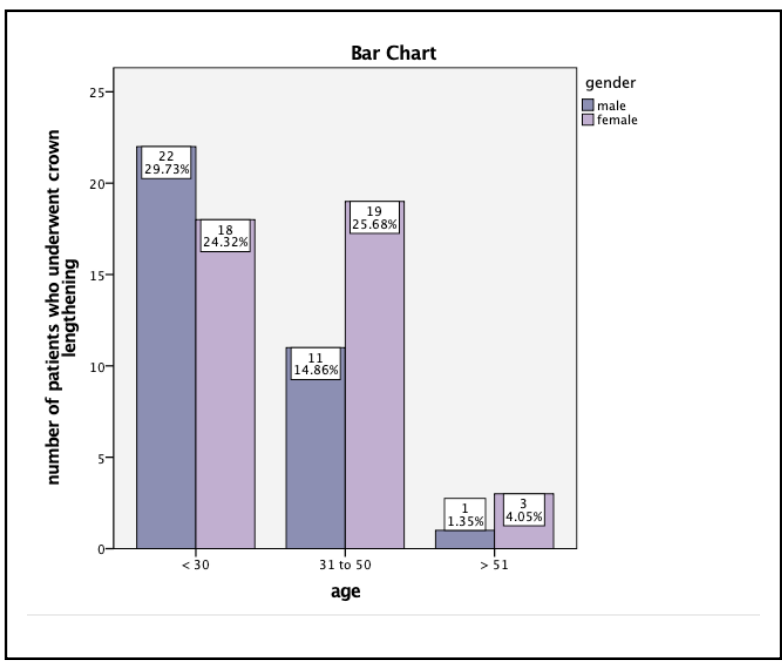

females, had undergone crown lengthening for endodontic therapy. Endodontic therapy includes RCT, restoration of subgingival caries, post and core single crown etc. A study by Al Sowygh shows the importance of crown lengthening in restorative dentistry [28]. Gummy Smile has been a restorative challenge for orthodontics to achieve aesthetic smiles. Gingival enlargement has been a common problem in orthodontic patients [29]. Study done by Ifthikhar et al showed the need for aesthetic crown lengthening in the orthodontic population. Arghavan Amini et al stated that individuals who were between the age group of 31 to 50 years need to undergo crown lengthening due to endodontic treatment over other age groups. Individuals with less than 30 years of age preferred crown lengthening due to aesthetic reasons (gummy smile post orthodontic treatment) [30]. This study shows that females had undergone laser crown lengthening more and it's done mostly in the upper arch.

\section{Acknowledgement and Declarations}

The authors are thankful to the dental institute for providing a platform to perform the research study. The authors declare no conflicts of interest.

\section{References}

[1]. Farista S, Kalakonda B, Koppolu P, Baroudi K, Elkhatat E, Dhaifullah E. Comparing Laser and Scalpel for Soft Tissue Crown Lengthening: A Clinical Study. Glob J Health Sci. 2016 Oct 1;8(10):55795. PubmedPMID: 27302447.

[2]. Gallucci GO, Belser UC, Bernard JP, Magne P. Modeling and characterization of the CEJ for optimization of esthetic implant design. Int J Periodontics Restorative Dent. 2004 Feb;24(1):19-29. PubmedPMID: 14984142.

[3]. Oh SL. Biologic width and crown lengthening: case reports and review. Gen Dent. 2010 Sep-Oct:58(5):e200-5. PubmedPMID: 20829153.

[4]. Huynh-Ba G, Brägger U, Lang NP. Surgical lengthening of the clinical crown: a periodontal concept for reconstructive dentistry. Periodontal Practice Today. 2007 Jun 1;4(3).

[5]. Perez JR, Smukler H, Nunn ME. Clinical evaluation of the supraosseous gingivae before and after crown lengthening. J Periodontol. 2007 Jun;78(6):1023-30. PubmedPMID: 17539715.

[6]. Lukram A, Sachdeva N, Kush Sahu A. Application of Laser in Prosthetic Dentistry: A. Int JDent Med Res. 2014NOV-DEC;1(4):100.

[7]. Kalsi HJ, Hussain Z, Darbar U. An update on crown lengthening. Part 1: Gingival tissue excess. Dent Update. 2015 Mar;42(2):144-6, 149-50, 153. PubmedPMID: 26058228.

[8]. Tanuja P, Babu BK, Krishna M. Laser-assisted crown lengthening and gin- 
gival depigmentation to enhance aesthetics-A case report. Ann Essen Dent. 2011;3:56-60.

[9]. Boj JR, Poirier C, Hernandez M, Espassa E, Espanya A. Case series: laser treatments for soft tissue problems in children. Eur Arch Paediatr Dent. 2011 Apr;12(2):113-7. PubmedPMID: 21473844

[10]. Jyothi S, Robin PK, Ganapathy D. Periodontal health status of three different groups wearing temporary partial denture. Research Journal of Pharmacy and Technology. 2017;10(12):4339-42.

[11]. Jain AR, Nallaswamy D, Ariga P, Ganapathy DM. Determination of correlation of width of maxillary anterior teeth using extraoral and intraoral factors in Indian population: A systematic review. World J Dent. 2018 Jan;9:68-75.

[12]. Jyothi S, Robin PK, Ganapathy D. Periodontal health status of three different groups wearing temporary partial denture. Research Journal of Pharmacy and Technology. 2017;10(12):4339-42.

[13]. Duraisamy R, Krishnan CS, Ramasubramanian H, Sampathkumar J, Mariappan S, NavarasampattiSivaprakasam A. Compatibility of Nonoriginal Abutments With Implants: Evaluation of Microgap at the Implant-Abutment Interface, With Original and Nonoriginal Abutments. Implant Dent. 2019 Jun;28(3):289-295. PubmedPMID: 31124826

[14]. Selvan SR, Ganapathy D. Efficacy of fifth generation cephalosporins against methicillin-resistant Staphylococcus aureus-A review. Research Journal of Pharmacy and Technology. 2016;9(10):1815-8.

[15]. Ganapathy D, Sathyamoorthy A, Ranganathan H, Murthykumar K. Effect of Resin Bonded Luting Agents Influencing Marginal Discrepancy in All Ceramic Complete Veneer Crowns. J ClinDiagn Res. 2016 Dec;10(12):ZC67ZC70. PubmedPMID: 28209008.

[16]. Salehi B, Lopez-Jornet P, Pons-FusterLópez E, Calina D, Sharifi-Rad M, Ramírez-Alarcón K, et al. Plant-Derived Bioactives in Oral Mucosal Lesions: A Key Emphasis to Curcumin, Lycopene, Chamomile, Aloe vera, Green Tea and Coffee Properties. Biomolecules. 2019 Mar 17;9(3):106. PubmedPMID: 30884918

[17]. Ranganathan H, Ganapathy DM, Jain AR. Cervical and Incisal Marginal Discrepancy in Ceramic Laminate Veneering Materials: A SEM Analysis. ContempClin Dent. 2017 Apr-Jun;8(2):272-278. PubmedPMID: 28839415.

[18]. Vijayalakshmi B, Ganapathy D. Medical management of cellulitis [Internet].Research Journal of Pharmacy and Technology. 2016; 9: 2067.

[19]. Kannan A. Effect of Coated Surfaces influencing Screw Loosening in Implants: A Systematic Review and Meta-analysis. World. 2017 Nov;8(6):496502.

[20]. Ashok V, Suvitha S. Awareness of all ceramic restoration in rural population. Research Journal of Pharmacy and Technology. 2016;9(10):1691-3.

[21]. Ashok V, Nallaswamy D, Benazir Begum S, Nesappan T. Lip Bumper Pros- thesis for an Acromegaly Patient: A Clinical Report. J Indian Prosthodont Soc. 2014 Dec;14(Suppl 1):279-82. PubmedPMID: 26199531.

[22]. Venugopalan S, Ariga P, Aggarwal P, Viswanath A. Magnetically retained silicone facial prosthesis. Niger J ClinPract. 2014 Mar-Apr;17(2):260-4. PubmedPMID: 24553044

[23]. Kannan A, Venugopalan S. A systematic review on the effect of use of impregnated retraction cords on gingiva. Research Journal of Pharmacy and Technology. 2018;11(5):2121-6.

[24]. Basha FY, Ganapathy D, Venugopalan S. Oral Hygiene Status among Pregnant Women. Research Journal of Pharmacy and Technology. 2018;11(7):3099-102.

[25]. Ajay R, Suma K, Ali SA, Kumar Sivakumar JS, Rakshagan V, Devaki V, Divya K. Effect of Surface Modifications on the Retention of Cement-retained Implant Crowns under Fatigue Loads: An In vitro Study. J Pharm Bioallied Sci. 2017 Nov;9(Suppl 1):S154-S160. PubmedPMID: 29284956.

[26]. Kois JC. The restorative-periodontal interface: biological parameters. Periodontol 2000. 1996 Jun;11:29-38. PubmedPMID: 9567954.

[27]. Lindhe J, Lang NP, Karring T. Clinical Periodontology and Implant Dentistry. Wiley; 2008; 2:1448.

[28]. Al-Sowygh ZH. Does Surgical Crown Lengthening Procedure Produce Stable Clinical Outcomes for Restorative Treatment? A Meta-Analysis. J Prosthodont. 2019 Jan;28(1):e103-e109. PubmedPMID: 29876998.

[29]. Jorgensen MG, Nowzari H. Aesthetic crown lengthening [Internet]. 2000. 2001; 27: 45-58. Available from: http://dx.doi.org/10.1034/j.16000757.2001.027001045.x

[30]. AMINI BA, Kiany F, Farsizadeh B. Indications \& predisposing factors of crown lengthening surgery. Available from: https://www.sid.ir/en/Journal/ ViewPaper.aspx?ID=422633

Special Issue on
"Prosthodontics and Maxillofacial Prosthetics"
Theme Edited by:
Yi-Fang Huang, Associate Professor, Chang Gum Me-
morial Hospital, Taiwan.
E-mail: yifang0324@gmail.com

